\title{
PM2.5 KONCENTRÁCIÓ MÉRÉSEK MOBIL MÉRŐMÜSZERREL BUDAPESTI BELVÁROSI KERÉKPÁR ÚTVONALON
}

\author{
Csapó Péter iD, Mészáros Róbert iD, Leelőssy Ádám \\ ELTE Meteorológiai Tanszék, 1117 Budapest, Pázmány Péter sétány 1/A \\ e-mail: pcsapo91@gmail.com,mrobi@nimbus.elte.hu, leelossyadam@gmail.com
}

\section{Bevezetés}

A hordozható légszennyezettség-mérő müszerekkel történő vizsgálatok napjainkban egyre nagyobb szerepet kapnak a városi légszennyezettség vizsgálata során. A mobil mérömüszerekkel lehetőség nyílik a helyhez kötött, automata mérőhálózat által mért adatoknál mind térben, mind pedig időben jobb felbontású adatok szerzésére. Tekintettel arra, hogy városi környezetben az egyik legnagyobb szennyező forrást a folyamatosan növekvő gépjármüállomány jelenti, kiemelt figyelmet kell fordítani a forgalmas útvonalak mikro-környezetében történő lokális szennyezőanyag-kibocsátás vizsgálatára. A gépjárművekből származó szennyezőanyag-kitettség halmozottan érinti az egyre növekvő városi kerékpáros társadalmat, ugyanis a kerékpárosok sok esetben kénytelenek a gépjármüvekkel osztozni az utakon, továbbá az ingázók legtöbbször csúcsidőben használják a kerékpárt. Csúcsidőben nagyobb számú autó közlekedik, amely során nemcsak a kipufogógázból, hanem az egyes alkatrészek (gumi, fék) kopásából is nagy mennyiségü részecske keletkezik. A városban történő aktív közlekedési mód választása számos egészségügyi, környezeti és gazdasági előnnyel jár, azonban a kerékpárosok a gépjármüvek által kibocsátott szennyezők közelségének következtében komoly expozíciónak vannak kitéve, továbbá a megnövekedett légzésszám és a mélyebb légvétel miatt nagyobb az elnyelt dózis is.

Jelen tanulmány célja, hogy budapesti, belvárosi környezetben, kerékpárutak mentén vizsgálja a $\mathrm{PM}_{2,5}$ koncentráció térbeli eloszlását és meghatározza azon területeket, útszakaszokat, ahol általában magasabb a $\mathrm{PM}_{2,5}$ koncentráció értéke. A méréseket egy előre meghatározott, 5 km-es útvonalon végeztük DustTrak 8532 típusú hordozható légszennyezettség-mérő müszerrel.

\section{A légszennyezés hatása a kerékpározásra}

A kerékpározás egészségre gyakorolt pozitív hatásai jól ismertek. A kerékpározás lehetővé teszi az emberek számára, hogy növeljék a fizikai aktivitásukat, ezáltal javítsák a szív- és érrendszeri kondíciójukat, miközben csökkentik a krónikus betegségek (cukorbetegség, szívés érrendszeri betegségek, bizonyos rákbetegségek) kockázatát, és az elhízást (Appariccio et al., 2016). Az egyre növekvő gépkocsiállomány, a fejlődő úthálózatok növekvő forgalma ugyanakkor jelentősen károsítják a környezetükben tartózkodók egészségét, köszönhetően a megnövekedett zajhatásoknak, a légszennyezésnek, valamint a baleseti kockázatoknak. Annak ellenére, hogy a legtöbb ember az idejének $>90 \%$-át zárt térben tölti (Klepeis et al., 2001), és viszonylag rövid időt töltünk közlekedéssel egy nap, az ez idő alatt elszenvedett expozíció jelentős mértékben járul hozzá a teljes napi kitettséghez (De Nazelle et al., 2017). A közlekedés okozta légszennyezettség veszélyeinek leginkább az aktív közlekedési módokat, a kerékpározást, vagy a gyaloglást előnyben részesítők vannak kitéve. A gyaloglás és a kerékpározás jelentős egészségügyi előnyökkel jár a megnövekedett fizikai aktivitás következtében. Ugyanakkor aktív közlekedés során megnő a szervezetbe bejutó légszennyező anyagok mennyisége, amely negatív hatásokat eredményezhet (Tainio et al., 2016). A közlekedési eredetủ lég- 
szennyezők már a rövid távú kitettség esetén is negatív hatással lehetnek többek közt a szívés érrendszerre, például a szívfrekvencia-variabilitásra, a vérnyomásra, a légzésre, illetve a tüdő müködésére is ( $\mathrm{Li}$ et al., 2017). A pillanatnyi egészségügyi hatásoknál fontosabbak lehetnek azok a nehezen meghatározható, krónikus változások, amelyeket a rendszeres, rövid idejü, de magas expozíció okozhat a napi szintü ingázás következtében. Fontos megjegyezni, hogy a légszennyezettség okozta kockázatbecslések nagyon nagy bizonytalanságot hordozhatnak magukban, tekintettel arra, hogy a kibocsátás nagy tér- és idöbeli változékonyságot mutat, továbbá a kibocsátott anyagok összetétele sem állandó. Az egészségre gyakorolt hatást befolyásolja a légszennyező anyag fajtája, dózisa, a kitettség hossza, továbbá a légszennyező anyagok keverékének összetett hatása. Mindemellett az egyes szervezetek is eltérően reagálhatnak azonos behatás esetén.

Kerékpározás során, a fokozott fizikai aktivitás hatására megnő a légzésszám, ezzel párhuzamosan pedig a légutakon keresztül a tüdőbe áramló, és ott lerakódó légszennyező anyagok mennyisége, amelyek miatt a légszennyező anyagok káros hatásai fokozódhatnak. Fokozott fizikai igénybevétel, mint például a kerékpározás esetén a percventilláció (a belélegzett levegő térfogata 1 perc alatt) 2-4,5-szer is magasabb lehet a motorizált üzemmódot választó utazókéhoz képest (Int Panis et al., 2010). Természetesen ez függ az egyének nemétől, korától, fizikai adottságaitól, egészségi állapotától, illetve az erőkifejtés mértékétől is (Cole, 2014), a kerékpár típusától, valamint az út- és terepviszonyoktól.

A mozgás során a légszennyezettségnek kitett egyének három okból kifolyólag tekinthetők fokozottan veszélyeztetettnek: a percventilláció növekedésével növekszik a belélegzett szennyező anyagok mennyisége is; a belélegzett levegő nagy része szájon át kerül a szervezetbe, elkerülve az orrban és a felső légutakban lévő természetes szüröket; a megnövekedett légáramlás hatására a szennyező anyagok a tüdő mélyebb területeire is lejutnak (Int Panis et al., 2010).

Városi környezetben, egészségügyi szempontból talán a legfontosabb légszennyező anyagok az aeroszol részecskék. Az aeroszol részecskék száma, mérete, alakja, felülete, kémiai összetétele, oldhatósága és eredete is eltérö. Méretük szerint alapvetően 3 kategóriát különböztetünk meg: ezek a durva részecskék, amelyek aerodinamikai átmérője 10 és 2,5 $\mu \mathrm{m}$ közé esik, finom részecskék, amelyek aerodinamikai átmérője 2,5 és $0,1 \mu \mathrm{m}$ közé esik, valamint az ultrafinom tartományt, amely a $0,1 \mu \mathrm{m}$-es aerodinamikai átmérőnél kisebb részecskéket foglalja magában (Pope and Dockery, 2006). Az aeroszol részecskék okozta egészségügyi hatások már nagyon alacsony expozíciós szinten jelentkezhetnek, és nincs olyan alsó határ, amely alatt bizonyosan nincs egészségkárosító hatása a kitettségnek (WHO, 2013). Az aeroszol részecskék ugyanis számos anyag keverékét jelentik, többek között vegyi anyagokat és nehézfémeket is, amelyek származhatnak természetes és antropogén forrásból egyaránt (Ramos, 2016).

A kerékpározást a világ számos pontján tanulmányozták, és vetették össze más utazási módok kitettségével (1. pl. Kaur et al., 2007). Az eredmények ugyanakkor sokszor ellentmondásosak; nincs konszenzus arra vonatkozóan, hogy egy meghatározott közlekedési mód a legmagasabb, vagy a legalacsonyabb kitettséggel járna.

A bemutatott, egymásnak sokszor ellentmondó eredmények számos okra vezethetők vissza. Ezek az eltérések rávilágítanak arra, hogy számos külső körülmény befolyásolja az egyes közlekedési módok esetében tapasztalható kitettséget: ilyen például az utak karakterisztikája, a meteorológiai viszonyok, az utastér szellőzése, a jármü üzemanyaga, a közlekedés volumene, vagy éppen a kibocsátó forrástól való távolság (Ramos et al., 2016; Kolluru et al., 2018). Emellett az egyes mintavételi módok is eltérőek, ami szintén megnehezíti az eredmények összehasonlítását, értelmezését.

Expozícióról akkor beszélünk, ha egy személy érintkezésbe lép egy bizonyos anyaggal, ugyanakkor a kerékpárosok szennyezőanyagnak való kitettség-vizsgálata során érdemesebb 
figyelembe venni a dózist, amely a testbe felszívódott, illetve lerakódott anyag mennyisége egy meghatározott időintervallumra vonatkoztatva. A megnövekedett fizikai igénybevétel a légzésszám növekedésével, valamint mélyebb lélegzetvétellel jár, így ilyen esetben magasabb a tüdőben lerakódó szennyezőanyagok mennyisége az ingázás során. A dózis meghatározása sokkal komplexebb az expozíciós szintek értékelésénél, tekintettel arra, hogy annak vizsgálatakor figyelembe kell venni a percventillációt, valamint az utazással eltöltött időt is, így kisebb expozíció esetén is nagyobb a kerékpárosok által belélegzett dózis (Ramos et al., 2016; Int Panis et al. 2010).

Az egészségkárositó hatás csökkentése céljából fontos lenne a kitettség minél nagyobb mértékủ csökkentése. Ennek egyik módja lehet a gépjármüvek (mint kibocsátó források) számának csökkentése, kerékpárok esetén a forrástól való távolság növelése, amelyre megoldást jelenthet az elkülönített kerékpárutak kialakítása, vagy a gyorsabb, de nagyobb forgalmú utak helyett olyan alternatív útvonalak választása, ahol a menetidő ugyan valamelyest növekedhet, ugyanakkor a kitettség számottevően kisebb. Számos tanulmány (pl. Jarjour et al., 2013; Jereb et al., 2018) jelentős közlekedési eredetủ szennyezőanyag kitettség csökkenést állapított meg alacsony forgalmú alternatív útvonalak használata esetén.

Fontos kiemelni, hogy az alternatív útvonal választásával az átlagos kitettség csökkenthetö, ellenben ha annak hossza jelentősen meghaladja a nagyobb koncentrációértékekkel jellemezhető, rövidebb útvonalét, az ott eltöltött megnövekedett idö ellensúlyozhatja ezt a csökkenést kumulatív kitettség vizsgálata során (Good et al., 2016). Az alternatív útvonalak meghatározása lehetséges olyan szennyezettségi térképek készítésével, amelyen meghatározhatók a nagy szennyezőanyag koncentrációval jellemezhető, ún. hot-spot területek, továbbá lehetőség nyílik olyan elkerülő útvonalak kijelölésére, ahol a szennyezőknek való kitettség, ezáltal az egészségügyi kockázatok csökkenthetők.

\section{Mobil mérések}

A légszennyezettségi viszonyok térbeli eloszlását városi környezetben általában levegökémiai modellekkel írják le (1. pl. Leelőssy et al., 2017; Kovács et al., 2019). A modellszimulációk mellett a hordozható légszennyezettség-mérő müszerek használata is egyre népszerübb, ugyanis ezek segítségével a személyes kitettséget közvetlenül lehet vizsgálni. A müszerek segítségével a mozgás során detektálható az adott pontokban és időpontokban fennálló levegöterheltségi szint, illetve annak kis idő- és térléptékủ változásai, ezáltal a modelleknél pontosabb, a hagyományos, helyhez kötött méróállomásokkal szemben pedig sokkal jobb felbontású képet kaphatunk a szennyezettség állapotáról. A fixen telepített méröállomások elönye, hogy a szennyezőanyag-koncentrációk nagy pontossággal mérhetők. Hátrányuk viszont, hogy az adatok térbeli felbontása alacsony, elhelyezésük a méretük miatt körülményes és fenntartási költségük is magas. Ezen kívül nem adnak közvetlen képet arról, hogy a városlakók egy kisebb területen mennyivel vannak kitéve nagyobb szennyezettségnek, mint például egy utcával messzebb. Ezen méréstípus megoldást nyújthat olyan rövid távú vizsgálatok során, ahol nagy térbeli felbontású adathalmaz megszerzésére van szükség, ami helyhez kötött mérőállomások segítségével nem lenne megvalósítható (Kaur et al., 2007). A mobil méréseket számos különbözö célra használják, pl. a személyi expozíció értékelése, eltérő közlekedési módok összehasonlítására, térbeli változékonyság vizsgálata, a szezonális és regionális változékonyság vizsgálata, levegöminőségi modellek validálása, vagy nagy térbeli felbontású légszennyezettségi térképek készítése (Farrell et al., 2015).

A hordozható légszennyezettség mérő müszerek alkalmasak lehetnek lokális kibocsátók meghatározására, hátrányuk azonban, hogy gyakran csak egy pillanatfelvételt tükröznek. Mindezek következtében a mérések során komoly figyelmet kell fordítani a tervezésre, és az adatok megfelelő kiértékelésére. A kampány céljától függően megfelelő számú ismétlődésre 
van szükség a kívánt megbízhatósággal és térbeli felbontással kapcsolatban (van den Bossche et al., 2015).

\section{A mérési program}

A légszennyezettség térbeli eloszlásának feltérképezése érdekében városi környezetben, különböző útvonalakon és különböző időszakokban végeztük méréseinket. Jelen tanulmányban egy belvárosi, $5 \mathrm{~km}$ hosszúságú útvonalon végzett mérési eredményeinket mutatjuk be.

A kiválasztott útvonal eltérő jellegü szakaszokat foglalt magában: a Gellért-hegy tövében húzódó, közepes gépjármü-forgalommal jellemezhető Duna-partot, amely Budapest legnagyobb ventillációs csatornája, alacsony forgalmú, magas házakkal körülvett szük utcákat, belvárosi parkos területet, illetve egy nagy forgalmú $2 \times 2$ sávos körutat, ahol a kerékpársáv közvetlenül a gépjármüvek mellett húzódik (1. ábra).

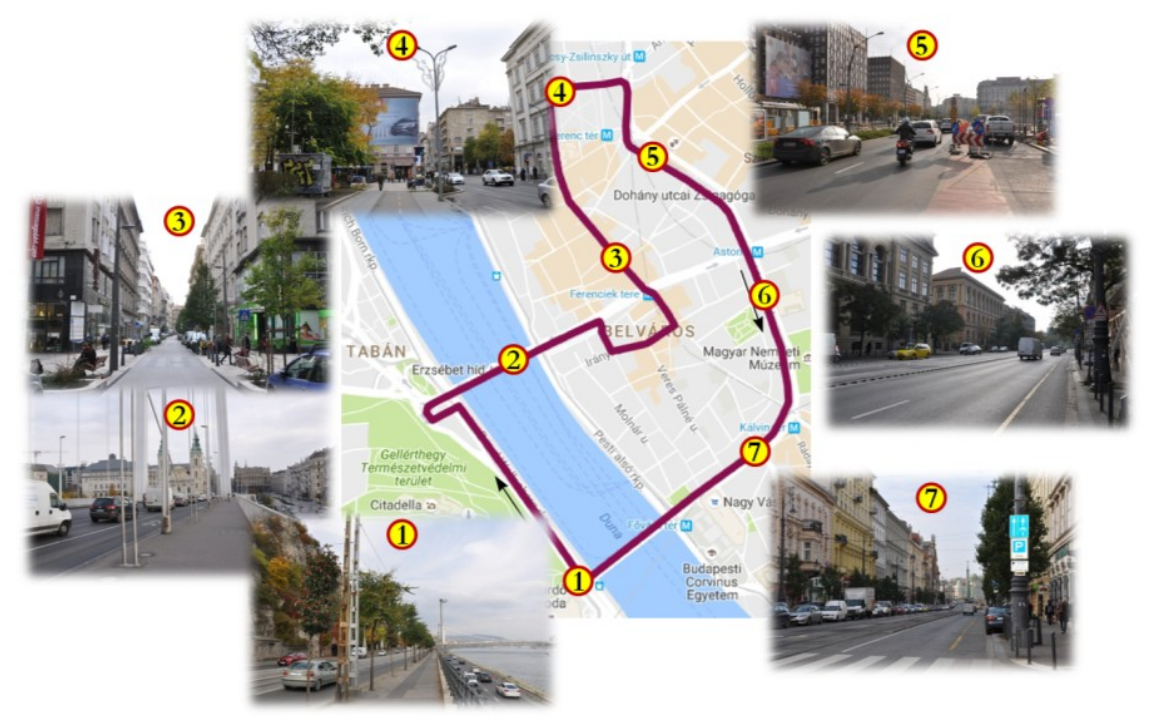

1. ábra: A vizsgált útvonal és annak néhány helyszíne.

Az adott útvonalon 2017. december 6-án (szerda) és december 7-én (csütörtök) összesen 10 alkalommal végeztünk méréseket. Egy-egy kör megtétele 20 percet vett igénybe.

A vizsgálatot DustTrak 8532 hordozható légszennyezettség-mérő müszerrel végeztük, amellyel folyamatosan rögzítettük a vizsgált útszakaszon a $\mathrm{PM}_{2,5}$ koncentrációt. A DustTrak 8532 egy lézer fotométer, amely a beszívott részecskékről szórt fényt feszültséggé alakítja, majd a feszültség nagyságából, kalibrációs értékekkel számolva határozza meg a tömegkoncentrációt. Tekintettel arra, hogy a mintázott aeroszol részecskék fizikai és kémiai tulajdonságai jelentősen eltérhetnek a gyári kalibráció során alkalmazott részecskék tulajdonságaitól, a DustTrak mérőmüszerek a porkoncentrációt esetenként jelentősen túlbecsülhetik (Li et al., 2006; Kam et al., 2011). Az eltérés függ az alkalmazott müszertől és a vizsgált környezettől. A méréseink során használt müszerek mérési adatait ezért összevetettük Budapest belvárosi környezetében, az Eötvös Loránd Tudományegyetem BpART méröállomásán (http://salma.web.elte.hu/BpArt/index.html; $\quad \varphi: 47^{\circ} 28^{\prime} 25,22^{\prime \prime}$ É.sz.; $\quad \lambda$ : 1903'48,65" K.h; $117 \mathrm{~m}$ tszf.) lévő, kétkörös kifagyasztó rendszerrel összekapcsolt kúpos elemű oszcilláló mikromérleg (TEOM-FDMS) által mért tömegkoncentráció értékekkel. A kalibrációs mérés 2018. május 31. és június 04. között történt, aminek összesített eredményeit az 1. táblázat tartalmazza (a kalibráció során két, azonos mobil müszert is vizsgáltunk, de a bemutatott mérések során csak az egyiket használtuk). 
1. táblázat: A DustTrak 8532 szenzorok által mért $\mathrm{PM}_{2.5}$ koncentrációk kalibrációs vizsgálatának összesített eredménye

\begin{tabular}{|c|c|c|c|c|c|}
\hline & $\begin{array}{c}\text { DustTrak I. } \\
\left(\mu \mathrm{g} / \mathrm{m}^{3}\right)\end{array}$ & $\begin{array}{c}\text { DustTrak II. } \\
\left(\mu \mathrm{g} / \mathrm{m}^{3}\right)\end{array}$ & $\begin{array}{c}\text { TEOM } \\
\left(\mu \mathrm{g} / \mathrm{m}^{3}\right)\end{array}$ & TEOM/DT I. & TEOM/DT II. \\
\hline minimum & 5,05 & 5,00 & 4,30 & 0,85 & 0,86 \\
\hline medián & 14,08 & 14,00 & 16,45 & 1,17 & 1,18 \\
\hline maximum & 38,20 & 38,25 & 37,70 & 0,99 & 0,99 \\
\hline átlag & 15,07 & 14,90 & 17,23 & 1,14 & 1,16 \\
\hline
\end{tabular}

A kalibrációs mérések eredményei alapján a hordozható mérőeszközök jó egyezést mutattak az etalon müszerrel (TEOM) való összehasonlítás során. A kerékpárutakon végzett mérések során azonban az aeroszol részecskék összetétele eltérő lehet, ami esetlegesen befolyásolhatja a mérés pontosságát. Ezért a vizsgálataink során nem abszolút mért koncentráció értékeket, hanem egy adott időszak átlagától való eltéréseket mutatunk be.

A vizsgált útvonalon a GPS koordinátákat egy L80-M39 Qectel GPS modul segítségével határoztuk meg és 30 másodperces időközönként rögzítettük. A DustTrak 8532 segítségével a $\mathrm{PM}_{2,5}$ koncentráció értékeket szintén félperces átlagolással határoztuk meg. A mérőmüszert a kerékpározás során egy hátizsákban helyeztük el, a légbeszívás zavartalanságát a hátizsákból kivezetett, a mérőmüszerhez tartozó vezetőcső (conductive tubing) biztosította. A kivezetés során komoly figyelmet fordítottunk arra, hogy a vezetőcső vége hozzávetőlegesen a belégzés szintjével azonos magasságban legyen. A légbeszívást 3 1/perc-es értékkel végeztük.

\section{Mérési eredmények}

Jelen dolgozatban 2 téli munkanap (2017. december 6. és 7.) során végzett mérések eredményeit mutatjuk be. A vizsgált $5 \mathrm{~km}$-es útvonalon (1. 1. ábra), mindkét napon délelötti idöszakban, összesen 10 kört tettünk (7 mérési időszak december 6-án, 3 mérési időszak december 7-én). A mérések során csapadék nem hullott.

A 2. ábrán az egyes napokon végzett mérési eredményeket tüntettük fel. Az egyes pontokban egy-egy útvonal körbejárás alatt mért átlagos koncentrációtól való eltérések láthatók összesítve. A mérések eredményei egyértelmüen kirajzolják, hogy melyek azok az útszakaszok, területek, ahol az útvonalon mért átlagkoncentrációnál magasabb, illetve alacsonyabb értékek tapasztalhatók.

A térképeken a zöld és kék színü pontok azon területeket mutatják, ahol az átlagosnál alacsonyabb koncentrációjú a $\mathrm{PM}_{2,5}$, míg a sárga és a piros színek az annál magasabb értékeket jelzik. A hot-spot területeknek tekinthető részeken, mint az Astoria, illetve a Ferenciek tere környéke (utóbbinál a vizsgálattal érintett napokon építési munkálatok zajlottak), jelentősen magasabb koncentrációt tapasztaltunk, mint a vizsgált útvonal többi részén. A budai oldalon az Erzsébet hídra történő felhajtásnál több esetben is lokális maximumot tapasztaltunk, amelynek oka lehet a rakpartról érkező gépjármüforgalom hídra történő nehézkes feljutása, illetve az ebböl adódó folyamatos fékezés, majd ismételt gázadás.

A zöldterületek pozitív hatásait az Erzsébet téren mérhető alacsonyabb értékek kitünően szemléltetik. Az ábrákon látszik a dunai szélcsatorna pozitív hatása is, amelynek eredményeként az átlagos szennyezettségnél alacsonyabb koncentrációkat mértünk a folyó közvetlen környezetének nagy részén és a hidakon (elsősorban a kisebb forgalmú Szabadság hídon).

Az ábrákon látszik, hogy adott útvonal szakaszra eső mérési pontok sürüsége sebességfüggő; azokon a területeken, ahol a folytonos haladás biztosított, ritkábbak a mérési pontok, 
míg az útvonalnak azokon a részein, ahol jelzőlámpák lassítják a haladást, a mérési pontok sürübbek.
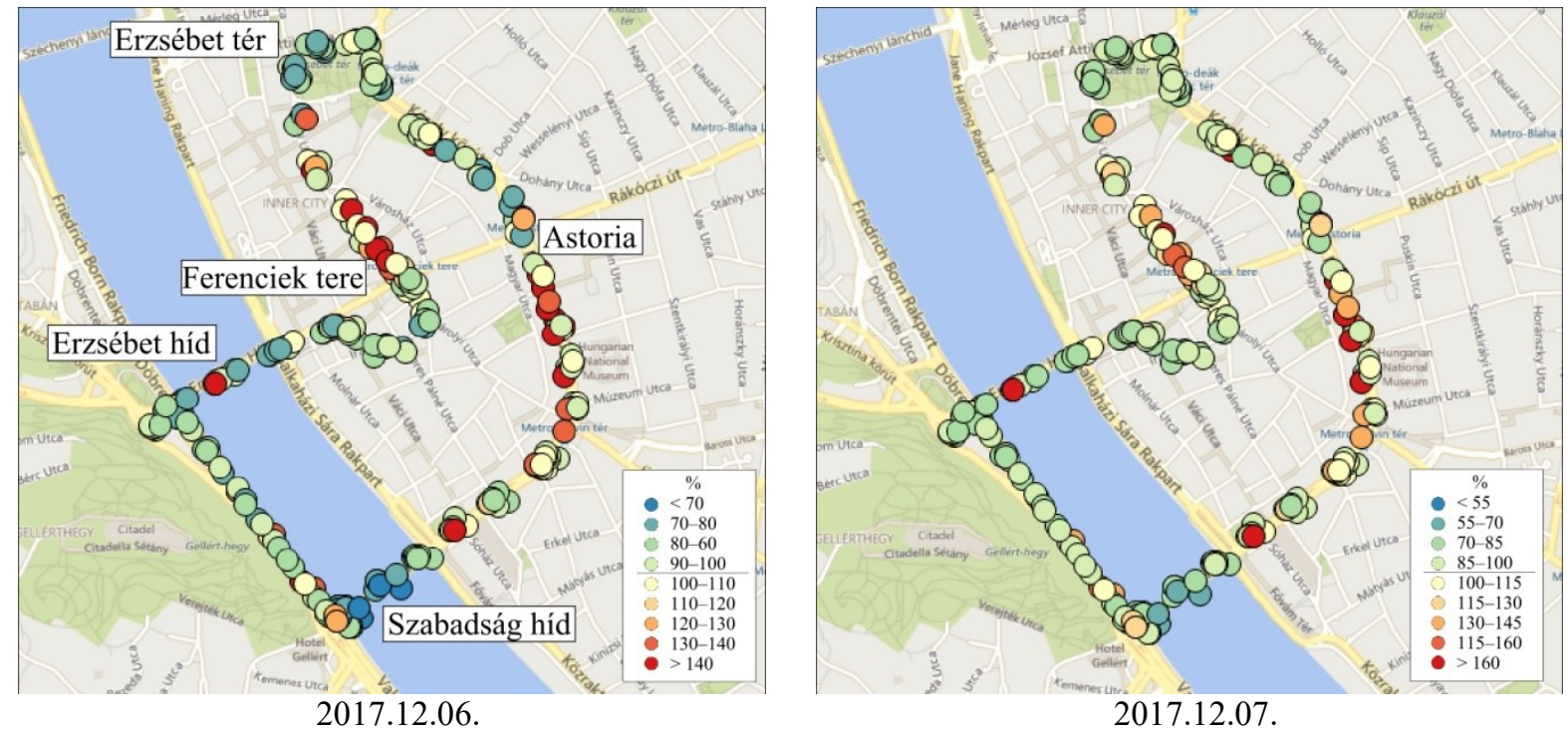

2. ábra: A 2017. december 6-án és december 7-én végzett mérések eredményei: a $\mathrm{PM}_{2,5}$-koncentráció átlaghoz viszonyított értékei \%-ban kifejezve a vizsgált útvonalon.

A légszennyezettség térbeli eloszlásáról már néhány mérési időszak is több, hasznos információval szolgál. A pontosabb vizsgálatokhoz azonban jóval több mérési időszakra van szükség. A méréseket folyamatosan végezzük, különböző évszakokban és napszakokban, esetenként adott időszakban egyszerre 2 útvonalon is. Jelen dolgozatban bemutatott méréseink során nyert tapasztalatok és eredmények nagyban hozzájárultak a mérések további folytatásának sikeréhez.

Köszönetnyilvánítás: A kutatásokat a Nemzeti Kutatási, Fejlesztési és Innovációs Alap K116506, K-128805 és K-128818 pályázatai támogatták.

\section{Hivatkozások}

Apparicio, P., Carrier, M., Gelb, J., Séguin, A.M., Kingham, S., 2016: Cyclists' exposure to air pollution and road traffic noise in central city neighbourhoods of Montreal. Journal of Transport Geography, 57: 63-69. https://doi.org/10.1016/j.jtrangeo.2016.09.014

Cole, C., 2014: Air pollution exposure and subclinical health impacts in commuter cyclists. The University of British Columbia (Vancouver). Thesis. 1-331. https://doi.org/10.14288/1.0107223

de Nazelle, A., Bode, O., Orjuela, J.P., 2017: Comparison of air pollution exposures in active vs. passive travel modes in Europe: A quantitative review - Environment International, 99: 151-160. https://doi.org/10.1016/j.envint.2016.12.023

Farrell, W.J., Weichenthal, S., Goldberg, M., Hatzopoulou, M., 2015: Evaluating air pollution exposures across cycling infrastructure types: Implications for facility design. The Journal of Transport and Land Use, 8(3): 1-19. https://doi.org/10.5198/jtlu.2015.702

Good, N., Mölter, A., Ackerson, C., Bachand, A., Carpenter, T., Clark, M.L.,. Fedak, K.M., Kayne, A., Koehler, K., Moore, B., L'Orange, C., Quinn, C., Ugave, V., Stuart, A.L., Peel, J.L,. Volckens, J., 2016: The Fort Collins Commuter Study: Impact of route type and transport mode on personal exposure to multiple air pollutants. Journal of Exposure 


Science and Environmental Epidemiology, 26: 397-404.

https://doi.org/10.1038/jes.2015.68

Int Panis, L., de Geus, B., Vandenbulce, G.,Villems, H., Deagraeuwe, B., Bleux, N., Mishra, V., Thomas, I., Meeusen, R., 2010: Exposure to Particulate Matter in Traffic: A Comparison of Cyclists and Car Passengers. Atmospheric Environment, 44: 2263-2270. https://doi.org/10.1016/j.atmosenv.2010.04.028

Jarjour, S., Jerrett, M., Westerdahl, D., de Nazelle, A., Hanning, C., Daly, L., Lipsitt, J., Balmes, J., 2013: Cyclist route choice, traffic-related air pollution, and lung function: a scripted exposure study. Environmental Health, 12,14. https://doi.org/10.1186/1476-069X$\underline{12-14}$

Jereb, B., Batkovic, T., Herman, L., Sipek, G., Kovse, S., Gregoric, A., Mocnik, G., 2018: Exposure to Black Carbon during Bicycle Commuting-Alternative Route Selection. Atmosphere, 9,21. https://doi.org/10.3390/atmos9010021

Kam, W., Cheung, K., Daher, N., Sioutas, C., 2011: Particulate matter (PM) concentrations is underground and ground-level rail systems of the Los Angeles Metro. Atmospheric Environment, 45: 1506-1516. https://doi.org/10.1016/j.atmosenv.2010.12.049

Kaur, S., Nieuwenhuijsen, M..J., Colvile, R.N., 2007: Fine particulate matter and carbon monoxide exposure concentrations in urban street transport microenvironments. Atmospheric Environment, 41: 4781-4810. https://doi.org/10.1016/j.atmosenv.2007.02.002

Klepeis, N.E., Nelson, W.C., Ott, W.R., Robinson, J.P., Tsang, A.M., Switzer, P., Behar, J.V., Hern, S.C., Engelmann, W.H., 2001: The National Human Activity Pattern Survey (NHAPS): a resource for assessing exposure to environmental pollutants. Journal of Exposure Analysis and Environmental Epidemiology 11: 231-252. https://doi.org/10.1038/sj.jea.7500165

Kolluru, S.S.R., Patra, A.K., Sahu, S.P., 2018: A comparison of personal exposure to air pollutants in different travel modes on national highways in India. Science of the Total Environment, 619-620: 155-164. https://doi.org/10.1016/j.scitotenv.2017.11.086

Kovács, A., Leelössy, Á., Mészáros, R., Lagzi, I., 2019: Online coupled modelling of weather and air quality of Budapest using the WRF-Chem model. Időjárás (in press).

Leelössy, A., Lagzi, I., Mészáros, R., 2017: Spatial and temporal pattern of pollutants dispersed in the atmosphere from the Budapest Chemical Works industrial site. Idojjárás, 121(2): 101-115.

Li, Z., Che, W., Frey, H.C., Lau, A.K.H., Lin, C., 2017: Characterization of $\mathrm{PM}_{2.5}$ exposure concentration in transport microenvironments using portable monitors. Environmental Pollution, 228: 433-442. https://doi.org/10.1016/j.envpol.2017.05.039

Pope, C.A., Dockery, D.W., 2006: Health effects of fine particulate air pollution: lines that connect. Journal of the Air \& Waste Management Association, 56: 709-742. https://doi.org/10.1080/10473289.2006.10464485

Ramos, C.A., 2016: Exposure to Air Pollutants During Physical Activity, 1-150. Doctoral thesis. Technische Universiteit Delft.

Ramos, C.A., Wolterbeek, H.T.,Almeida, S.M., 2016: Air pollutant exposure and inhaled dose during urban commuting: a comparison between cycling and motorized modes. Air Quality Atmosphere \& Health, https://doi.org/10.1007/s11869-015-0389-5

Tainio, M., de Nazelle, A.J., Gotschi, T., Kahlmeier, S., Rojas-Rueda, D., Nieuwenhuijsen, M.J., de Sa, T.H., Kelly, P., Woodcock, J.,2016: Can air pollution negate the health benefits of cycling and walking? Preventive medicine, 87: 233-236. https://doi.org/10.1016/i.ypmed.2016.02.002

Van den Bossche, J., Peters, J., Verwaeren, J., Botteldooren, D., Theunisa, J., De Baets, B., 2015: Mobile monitoring for mapping spatial variation in urban air quality: development 
and validation of a methodology based on an extensive dataset. Atmospheric Environment, 105: 148-161. https://doi.org/10.1016/j.atmosenv.2015.01.017

WHO, 2013: Health effects of particulate matter- Policy implications for countries in eastern Europe, Caucasus and central Asia, 1-12.

http://salma.web.elte.hu/BpArt/index.html

\section{ORCID}

Csapó $P$. (D) https://orcid.org/0000-0003-3252-1217

Mészáros R. (iD) https://orcid.org/0000-0002-0550-9266

Leelössy Á. (D) https://orcid.org/0000-0001-9583-0127 